\title{
Beyond the Impasse of African Industrial Development: The Case of Botswana, Tanzania and Zambia
}

\author{
Stephen Miti Kapunda*
}

\begin{abstract}
The thrust of this article is to examine critically the importance, performance and under-weighting of the industrial sector in Africa focusing on three countries, Botswana, Tanzania and Zambia, in the Southern African Development Community (SADC) region. The article shows that both theoretical and empirical evidence indicates somewhat unsatisfactory industrial performance. The article attempts to explain the way forward (beyond the impasse), by providing alternative approaches, opportunities and recommendations.
\end{abstract}

\section{Résumé}

Cette étude a pour objet d'examiner de manière critique l'importance, la performance et la médiocrité du secteur industriel en Afrique subsaharienne notamment dans trois pays membres de la SADC - le Botswana, la Tanzanie et la Zambie. Il y est signalé que des données factuelles tant théoriques qu'empiriques indiquent une performance industrielle plutôt insatisfaisante. L'auteur s'applique à expliquer la marche à suivre (pour sortir de l'impasse) en proposant des approches, possibilités et recommandations alternatives.

\section{Introduction}

In general, industrial development in Africa seems to be given less weight than it deserves; yet it is well documented in the literature that industrialisation has several advantages. The main reason for under weighting industrialisation stems largely from over emphasising the Ricardian theory of comparative advantage in favour of the primary sector (agriculture and

* Department of Economics, University Dar es Salaam, Tanzania. Currently at the Department of Economics, University of Botswana.

Email: Kapunda@mopipi.ub.bw 
mining) even in the long term. The current emphasis on international competition and globalisation tends to support this trend. No wonder the manufacturing sector's contribution to gross domestic product (GDP) in sub Saharan Africa has been stagnant at about 17 per cent since 1980. In some countries like Botswana, Tanzania and Zambia it has declined. This seems to contradict the conventional industrial development trends or patterns.

The main objective of this article is to examine critically the importance, performance and under-weighting of the industrial sector in the selected SADC countries, thereby providing alternative approaches, industrial opportunities and recommendations. The focus is on Botswana, Tanzania and Zambia, countries which have made great efforts towards economic diversification.

The rest of the article is organised as follows: section two explains propositions on industrialisation and comparative advantage in Africa. Section three examines industrial performance in Africa focusing on the three SADC countries. Alternative approaches, industrial opportunities and recommendations are presented in section four.

\section{Propositions on industrialisation and comparative advantage in Africa}

Proponents of industrialisation in Africa use propositions which give more weight to industrial development than primary sector development, especially in the long run. Industrialisation is considered to have several advantages. First, diversification away from the primary sector towards manufacturing reduces risks and vulnerability to the long term deteriorating commodity terms of trade and the associated loss in real income. Second, unlike the primary sector, the industrial sector has more forward and backward linkages with other sectors, especially agriculture and mining. Third, industrialisation contributes significantly to employment creation if the right techniques are chosen. Fourth, industrialisation has a relatively greater possibility of technological transfer and adaptation and the creation of technology.

In general, industrialisation ensures economic independence in the long run (Kapunda 2005: 176). However, as noted in the Introduction, industrialisation in Africa seems to be given less weight than it deserves. The sources of under weighting industrialisation in Africa are essentially (i) the Ricardian theory of comparative advantage; (ii) the unbalanced industrial growth theory in Africa; and (iii) an over emphasis on foreign investment. These sources and their relevant propositions are elaborated hereunder: 
(i) The Ricardian theory of comparative advantage seems to over emphasise the development of agriculture and mining in Africa at the expense of industrial development even in the long run. This has been the trend since the colonial era. One extreme proponent of the comparative law is quoted as writing:

Given Africa's large endowment of land, its comparative advantage is inevitably natural resources, and so Africa should forget about a manufacturing future. Africa can only keep manufacturing activities alive as 'pests' not adding value at world prices and being parasitic on the real economic activities that directly or indirectly pay for their survival. ${ }^{1}$

Nevertheless, African countries have realised the importance of industrialisation and the hidden agenda of proponents of anti industrialisation in Africa. Immediately after independence many countries, including Botswana, Tanzania, and Zambia, started with import substitution strategies to replace imports by goods manufactured domestically in order to meet domestic demand. With the advent of structural adjustment programmes, intensive international competition and globalisation, many countries have shifted to an export oriented strategy which requires production of quality goods for export at low prices. Most countries are finding this to be an inevitable challenge.

At least two negative implications of globalisation for industrial development are apparent. First, the resultant free trade encourages the availability of relatively cheap imported products like textiles from China, which stimulates stiff competition and tends to cripple local industries. Second, the expected reduction or removal of subsidies on important industries for rural poverty alleviation (micro, small and medium industries) and other strategic industries, affects their performance negatively.

(ii) Unbalanced industrial growth theory underscores the importance of only micro, small and medium industries and consumer good industries (as if this was the end of the road - the impasse) at the expense of intermediate and capital goods industries. This is in line with the activities of most foreign investors who concentrate on consumer goods which have a relatively short pay back period - a condition for quick profits. However, intermediate and capital goods industries, though expensive, are strategic in ensuring industrial linkages, intensive use of domestic inputs, and economic independence in the long run.

(iii) Over emphasis on foreign investment is at the expense of local initiatives, and the adoption and creation of technology. Practically all African countries use imported technology. It is the responsibility of African countries 
to learn and adopt such technology and in the long term create their own technology.

\section{Industrial performance in Sub Saharan Africa: The case of Botswana, Tanzania and Zambia}

From the previous section it is not surprising to learn that the manufacturing contribution to GDP in sub Saharan Africa has been stagnant at about 17 per cent since 1980. The manufacturing sectoral contribution to GDP has been falling in many African and SADC countries. In Botswana, for example, it has fallen from 5 per cent in 1980 to the current approximate 4 per cent. In Tanzania and Zambia it has declined from 9 per cent and 18 per cent to 8 and 12 per cent respectively in the same period. This seems to contradict the conventional industrial development trends (patterns). For details see Table 1.

Table 1: Comparative Structure of Output in sub Saharan Africa and in Botswana, Tanzania and Zambia (percentages)

\begin{tabular}{lccccc}
\hline & & $\begin{array}{c}\text { Sub-Saharan } \\
\text { Africa }\end{array}$ & Botswana & Tanzania & Zambia \\
\hline Agriculture & 1980 & 18 & 11 & 52 & 14 \\
& 1990 & 18 & 5 & 48 & 18 \\
& 2000 & 18 & 3 & 48 & 17 \\
& $2004+$ & 17 & 3 & 46 & 17 \\
Industry* & 1980 & 39 & 45 & 15 & 41 \\
& 1990 & 34 & 56 & 16 & 45 \\
& 2000 & 32 & 45 & 14 & 40 \\
& $2004+$ & 32 & 45 & 16 & 45 \\
& 1980 & 16 & 5 & 9 & 18 \\
& 1990 & 17 & 5 & 9 & 20 \\
& 2000 & 17 & 5 & 7 & 11 \\
& $2004+$ & 17 & 4 & 8 & 12 \\
\hline
\end{tabular}

Notes: * Industry defined broadly to include manufacturing, mining and public utilities. + Estimates.

Sources: Compiled by the author using data from World Bank (2002, 2001, 1984), United Republic of Tanzania (2005), Republic of Botswana (2005). 


\section{The case of Botswana}

Before the advent of globalisation the main industrial strategy was import substitution as documented in the 1984 Industrial Development Policy for Botswana. That strategy was appropriate at that time for the closed economies of the Southern African region (Republic of Botswana 1998: 1).

In 1998, however, there was a need to revise the policy due to the increasing intensity of international competition and globalisation and the great need to diversify economically from minerals to the industrial sector, among other sectors. The resultant 1998 Industrial Development Policy shifted the strategy to export oriented industrialisation. This policy is applicable up to now.

Nevertheless, the performance of the industrial sector, particularly the manufacturing sector, is not very satisfactory. The manufacturing sectoral contribution to GDP has declined to the current 4 per cent from 6 per cent at independence in 1966 or 5 per cent in 1980. Even the contribution of the manufacturing sector to total employment or total export is still low (about 10 per cent). The manufacturing sector however, grew on average by 5 per cent between 1996 and 2004. The mining sector (mainly diamonds) dominates the contribution to GDP (36 per cent) as shown in Table 2 .

Table 2: Manufacturing Contribution to GDP, Employment and Total Export in Botswana (percentage)

\begin{tabular}{cccccc}
\hline & \multicolumn{3}{c}{ Contribution to GDP } & & \multicolumn{2}{c}{ Manufacturing Contribution } \\
Year & Manufacturing & Mining & Agriculture & Employment & Export \\
\hline 1985 & 3.2 & 50.7 & 5.4 & 8.5 & 14.8 \\
1998 & 4.6 & 32.1 & 3.1 & 9.6 & 24.0 \\
2000 & 4.1 & 36.5 & 2.7 & 11.2 & 10.7 \\
2001 & 4.0 & 34.7 & 2.6 & 11.0 & 10.0 \\
2002 & 3.9 & 35.9 & 24 & 10.6 & 9.5 \\
2003 & 3.7 & 34.7 & 25 & 10.6 & 9.0 \\
$2004 *$ & 4.0 & 36.0 & 25 & 10.7 & 10.0 \\
\hline
\end{tabular}

Source: Calculated by the author using Central Statistical Office (CSO) data.

Although the mining sector's contribution to total exports has increased from 76 per cent in 1998 to the current 90 per cent, Botswana still maintains the policy of economic diversification away from mining due to the future risk and uncertainty of the mining sector. The industrial sector is still regarded as central to economic diversification despite its challenges and problems. It is, however, now clear that the industrial sector alone cannot ensure economic 
diversification. Other sectors should also be actively involved. Regarding employment, for instance, the manufacturing sector alone cannot be considered a panacea for Botswana's unemployment problem. In fact it is the service sector, because of its labour intensity, that can address the unemployment problem more effectively.

Regarding the impact of globalisation on industrial development, Botswana faces stiff competition from the more industrialised economies of South Africa, Europe, North America and others because of the intensity of free trade promoted by the SADC, the Southern African Customs Union (SACU), the World Trade Organization (WTO), and other organisations and trade agreements.

The current flood of imported cheap products, especially textiles from East Asia, tends to be a great challenge to the country's industrial development. Liberalisation and globalisation have started putting pressure on the government to reduce direct subsidies for the micro, small and medium enterprises and other industries to conform to the rules of international organisations such as the WTO to which Botswana is a signatory. Micro, small and medium enterprises are important in Botswana as they contribute 30 to 40 per cent to GDP. Furthermore, about 50 per cent of formal employment is estimated to arise from these enterprises. ${ }^{2}$

The possible future removal of preferential treatment for Botswana beef due to globalisation forces is likely to lead to a fall in beef prices and result in an adverse impact on the rural population which depends heavily on livestock.

\section{The case of Tanzania}

After independence in 1961 Tanzania embarked on industrialisation centred on an import substitution strategy. In 1967 the Arusha Declaration announced the nationalisation of the major means of production. Like Botswana, with the advent of intensive international trade and globalisation, an export oriented strategy was adopted. In 2003 Tanzania came up with a National Trade Policy for competitive and export led growth. However, the country faces stiff competition within the two communities - East African Community (EAC) and Southern African Development Community (SADC) and beyond. Regarding industrial performance, as noted earlier, the manufacturing sector contribution fell slightly from 9 percent in 1980 to 8 per cent in 2004 .

The contribution of the industrial sector to total exports declined from about 11 per cent in 1985 to 7 per cent in 2004. However, recent real growth rates of the manufacturing sector are impressive. The growth rate increased from 4.8 in 2000 to 8.6 in 2004. The recent increase in production has been mainly a result of the rehabilitation of divested or privatised enterprises, the 
establishment of new industries, and an improvement in the supply of electricity and water. Industrial employment has been higher than before largely as a result of the increase of private and informal enterprises, especially the small and medium enterprises. About a third of GDP come from the small and medium enterprises in Tanzania. ${ }^{3}$

Table 3: Manufacturing Contribution to GDP and Total Export and Employment Growth in Tanzania (percentage)

\begin{tabular}{|c|c|c|c|c|c|}
\hline \multirow[b]{2}{*}{ Year } & \multicolumn{3}{|c|}{ Contribution to GDP } & \multicolumn{2}{|c|}{ Manufacturing sector } \\
\hline & Manufacturing & Agriculture & Mining & $\begin{array}{l}\text { Employment } \\
\text { (growth rates) }\end{array}$ & $\begin{array}{c}\text { Export/ } \\
\text { Total Export }\end{array}$ \\
\hline 1985 & 9.1 & 50.0 & 1.5 & 1.8 & 10.7 \\
\hline 1998 & 8.4 & 49.1 & 2.0 & 5.5 & 6.1 \\
\hline 2000 & 8.3 & 48.1 & 2.3 & 6.5 & 6.5 \\
\hline 2001 & 8.3 & 48.0 & 2.5 & 6.0 & 7.2 \\
\hline 2002 & 8.4 & 47.5 & 2.7 & 10.3 & 7.3 \\
\hline 2003 & 8.6 & 46.7 & 3.0 & 8.0 & 6.8 \\
\hline $2004 *$ & 8.4 & 46.4 & 3.2 & - & 7.2 \\
\hline
\end{tabular}

Source: Calculated by the author using Tanzania Economic Survey (2005) data.

The positive impact of globalisation seems to have contributed to the recent impressive trends. First, a few industrial products have improved their market competitiveness. Products with remarkable sales performance include beer, cigarettes, soft drinks, bottled water, tyres and textiles. The increase in sales is mainly to an increase in quality, an efficient distribution system and rigorous promotion and advertisement. Second, joint ventures and privatisation have also contributed positively in some cases, for example, beer. Third, positive impacts on small industrial enterprises have also contributed to the recent trends. These include import liberalisation on the supply of inputs and spare parts and domestic trade liberalisation.

However, the negative implications of globalisation, if not addressed, may well blur the future performance of the industrial sector. These include, as in the case of Botswana, the flood of imported cheap products, especially used textiles (mitumba) and the closure of some small plants and even large ones which cannot produce high quality products at minimum production costs so that they can sell them at competitive prices. 


\section{The case of Zambia}

At independence in 1964 the economy of Zambia was dominated by the mineral sector. In 1965 mining accounted for about 40 per cent of GDP. Industries beyond those related to mining were few and concentrated in the Copper Belt Region and along the main railway line (World Bank 1993).

Like Tanzania, Zambia in 1968 employed interventionist policies which partly led to the nationalisation of its main industries and the amalgamation of most of the non financial institutions to form parastatals as announced in the Mulungushi Declaration. ${ }^{4}$ During this time, state-led import substitution industrialisation was the industrial policy (Kalima 2001: 4).

With the advent of structural adjustment programmes in 1985 and subsequent intensive international competition and globalisation, the industrial policy became more open.

Regarding the performance of the manufacturing sector relative to other sectors, Table 4 shows the sectoral contribution to GDP.

Table 4: Manufacturing Contribution to GDP Relative to Other Sectors in Zambia

\begin{tabular}{lcccc}
\hline Year & Manufacturing & Agriculture & Mining & Services \\
\hline 1980 & 18 & 14 & 20 & 44 \\
1985 & 23 & 13 & 16 & 45 \\
1990 & 32 & 18 & 9 & 37 \\
2000 & 11 & 17 & 9 & 57 \\
$2004^{*}$ & 12 & 18 & 8 & 55 \\
\hline
\end{tabular}

Note: * Estimate.

Source: Calculated by the author using data from various World Bank Development Reports.

It is apparent that the industrial sector contribution to GDP dropped from 18 per cent to about 12 per cent in 2004. The share of the mining sector in GDP has also been declining substantially in the same period.

\section{Alternative approaches, opportunities and recommendations}

One recommendation is that the theory of comparative advantage should not be misinterpreted or overused to slow or discourage industrialisation in Africa. This should also apply to the current processes surrounding increased international competition and globalisation.

Second, the positive aspects of international competition and globalisation should be used to encourage industrialisation. With stiff competition the 
manufacturing and other sectors in Africa should be more cost conscious than ever before. Similarly, they have to be quality conscious, thereby improving efficiency, productivity and profitability. The industrial sector should also take advantage of international trade opportunities such as the African Growth and Opportunity Act (AGOA) and other favourable agreements. Furthermore, since globalisation is expected to reduce technological and other traditional problems of the industrial and other sectors through technical and financial aid from international economic institutions as per WTO negotiations, Africa should take advantage of the implied opportunity.

Third, African governments should guide the free market forces. The current increasing intensity of free trade and globalisation may be misused by profit seekers and monopolists against industrial development and consumers if the visible hands of governments do not intervene through competition policies and other mechanisms to ensure fair competition. Government should continue to support small and medium enterprises with a view to gradually decrease the support once the business has taken off to sustainability. This also applies to infant industries - as noted in the paper small and medium industries are important in contributing to GDP and employment, especially in rural areas where the majority of the poor live in African economies as in Botswana, Tanzania and Zambia. These enterprises should also increase productivity and produce quality products and minimise costs. They may compete indirectly through niche marketing by identifying segments of markets which they can serve better than large firms. They may try to promote exports to markets not tapped by global investors such as exporting African crafts and labour intensive products to the USA, Europe and other parts of the world.

Governments should also play a leading role in developing large strategic industries, especially intermediate and capital good industries, which are not given priorities by private investors due to their long pay back periods. Governments should encourage foreign investors to invest in such industries by providing effective investment incentives such as long tax payment holidays or even embarking on joint ventures with them (Kapunda 2003: 15).

Government should also provide incentives to Africans who excel in innovations and technological performance.

Lastly, the three countries, Botswana, Tanzania and Zambia and other SADC countries should take advantage of the industrial and other benefits of integration such as having common industrial strategies, trade agreements and common markets. This also may apply to other regional co-operation and organisations in West Africa and other parts of Africa. 


\section{Notes}

1. Woods, A. and K. Berge (1977), quoted in Collier (1999).

2. For details see Kapunda (2005).

3. Ibid.

4. The 1968 Mulungushi Declaration is comparable to the 1967 Arusha Declaration in Tanzania which was used to nationalise the means of production.

\section{References}

Central Statistical Office (CSO), 2004, Botswana Statistical Year Book, Gaborone: CSO.

Collier, P., 1999, 'Globalization: How Should Africa Respond', AERC Newsletter, 3 March.

Kalima, B.M., 2001, 'The Role of Financial Markets and Economic Growth in Zambia', MA Dissertation, University of Botswana, Gaborone.

Kapunda, S.M., 2005, 'The Role of Industry in Diversification and Sustainable Economic Development in Less Developed Countries', in Narayana, N., Economic Development Issues and Policies, Vol. 1, New Delhi: Serial Publications.

Kapunda, S. M., 2003, 'Reform and Industrial Development and Trade in East Africa: The Case of Tanzania', Paper presented to CODESRIA Conference, Addis Ababa.

Republic of Botswana, 2005, Annual Economic Report, Gaborone: Republic of Botswana.

Republic of Botswana, 1998, Industrial Development Policy, Gaborone: Republic of Botswana.

United Republic of Tanzania, 2005, Economic Survey, Dar es Salaam: United Republic of Tanzania.

World Bank, 2002, World Development Report, Oxford: Oxford University Press. World Bank, 2001, World Development Report, Oxford: Oxford University Press. World Bank, 1993, World Development Report, Oxford: Oxford University Press. World Bank, 1984, World Development Report, Oxford: Oxford University Press. 